https://doi.org/10.31874/2309-1606-2018-22-1-199-210

УДК: 17.025

\title{
Ганс-Мартін 3ACC
}

Hans-Martin SASS

(Ruhr- University, Germany)

Hansmartin.Sass@rub.de

\section{ЗАСАДИ БІОЕТИКИ}

3 ПРОТЕСТАНТСЬКОÏ ТРАДИЦІї ${ }^{1}$

(частина 2) ${ }^{2}$

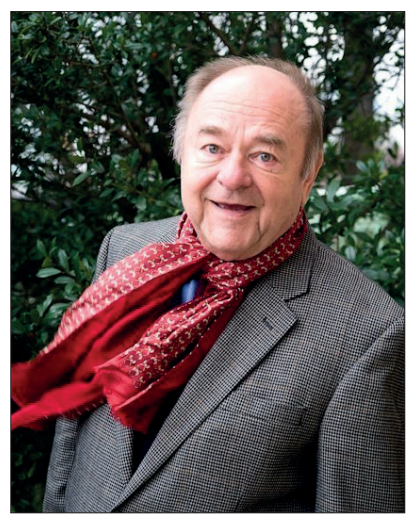

(переклад з німецької і примітки Ганни

Губенко)

\section{Від перекладача}

Ганс-Мартін Засс, Почесний професор філософії (Рурський Університет, Бохум, Німеччина); Засновник і член правління Центру медичної етики, Бохум, Німеччина; Почесний старший науковий співробітник Інституту Кеннеді Джорджтаунського Університету, Вашингтон, округ Колумбія; Почесний професор науково-дослідного центру біоетики, Пекін. Він написав більше 60 книг і брошур, більше 250 статей у фахових журналах. Редактор серії Ethik in der Praxis / Practical ethics, Muenster: Lit, Засновник та співредактор брошур «Medizinethische Materialien», Бохум: ZME. Читав лекції в Аргентині, Австрії, Бельгії, Болгарії, Бразилії, Канаді, Китаї, Хорватії, Чехії, Індії, Ірані, Ізраїлі, Італіі, Японіі, Франціі, Нідерландах, Філіппінах, Польщі, Португалії, Росії, Іспанії, Швейцарії, Тайвані.

Наразі ми представляємо другу частину перекладу статті від № 2/2016. У першій частині ми розкрили перші 3 розділи публікації:

1. Виникнення та зміст поняття біоетики;

2. Антропоцентричний імператив Канта і біоетичний імператив Яра;

3. Співчуття як транс-культурна чеснота та категоричний імператив.

Аналізуючи погляди Фріца Яра в контексті становлення біоетичних знань, Г.-М. Засс доходить висновку, що фактично пастор із Галле, не маючи впливу тогодення, тим не менш заклав термінологічні й концептуальні засади для розвитку сучасного розуміння біоетики.

\footnotetext{
1 (c) Ганна Губенко, переклад з німецької, 2018.

2 Першу частину статті див.: Філософія освіти. Philosophy of Education, 2016, №2 (19), 221-230.
} 


\section{Анотація}

Термін та концепція біоетики (Bio-Ethik) були розроблені Фріцем Яром (Fritz Jahr), протестантським пастором в місті Галле, у 1927 році, тобто задовго до того, як у 1970-х в Америці виникла біоетика у сучасному розумінні й поширилася по всьому світу. Біоетичний імператив Яра, під впливом християнських та гуманістичних традицій від Франциска Асизького до Артура Шопенгауера, а також філософії буддизму, набув такого визначення: «Поважай все жмиве взагалі як самого себе $i$, якщо це можливо, стався до всього живого як до самого себе!». Яр інтерпретує заповідь «Не вбий» як принцип «загальної моралі», який включає в себе зобов'язання піклуватися про своє здоров'я, громадську охорону здоров'я й медико-санітарну освіту в більш широких рамках універсального біоетичного імперативу.

У статті артикулюються актуальні для сьогодення думки щодо біоетичного імперативу, який виступає не тільки об'єктом міждисциплінарного дослідження, а й практичним підходом щодо набуття відповідальності та екологічного образу мислення. Дидактичні міркування Яра виходять за межі патерналістичного виховання, вони вказують на змістовну та методологічну ціль викладання, на етичний дискурс. На думку Яра, етика не регулює філософські, теологічні чи політичні знання, не виступає як диктатура способу поведінки. Етика це ведення дискусій, культура обговорення, спілкування. Слідуючи філософії Яра, професор Ганс-Мартін Засс сформулював гео-етичний імператив: «Поважай Матінку Землю і все природнє життя як таке, за яке відповідальною є людина, яке є самоціллю, і поводься по можливості саме таким чином!». Саме повага до усього живого має бути основою взаємовідносин між людиною і тваринами, рослинами та природою в цілому, включаючи систему охорони здоров'я, діяльність освітніх та дослідних організацій.

Пастор Фріи Яр, який за доби свого життя не мав безпосереднього впливу на розвиток концепції, тим не менш побудував першу протестантську основу для сучасних богословських та етичних концепцій в галузі медичної етики, біоетики й інвайронментальної етики.

Ключові слова: Фріи Яр, біоетика, біоетичний імператив, категоричний імператив, гео-етичний імператив.

\section{4. П'ята заповідь як біоетичний моральний закон}

У 1934 році теолог та педагог Яр у журналі «Соціальна та сексуальна етика» використовує інтерпретацію п’ятої заповіді, щоб проілюструвати універсальну та нормативну функції біоетичного імперативу у трьох різних підходах: (а) п’ята заповідь як вираз загального морального закону; (б) як етичний обов'язок самозбереження та самовіддачі; (c) як біоетичний імператив (1) (Jahr, 1934: 101-102; 363-364).

А: «Як ми робимо добро?» - На це питання дає відповідь «золоте правило»: «Усе, що ви бажаєте, щоб люди вам чинили, те ви чиніть їм» 
(Матвій 7, 12; Лука 6, 31). «Категоричний імператив» Канта: «Чини так, щоб максими, якими керується твоя воля, могли б стати принципами загального законодавства». Проте такі формулювання дають лише, так би мовити, формальну характеристику «правильного» способу поведінки. Не дивлячись на це, мотивом поведінки може стати навіть крайній егоїзм, а саме, свого роду, взаємозгода: «Не роби мені нічого, тоді і я нічого тобі не зроблю». Як про це пише, наприклад, Артур Шопенгауер у своєму трактаті «Про основу моралі». У кантівському формалізмі золотого правила та утилітарній етиці договору уникають того, що мотивом може бути «любов, як виконання морального закону» (Послання до Римлян 13,10), і звертають увагу на конкретну змістовну форму, яку Артур Шопенгауер назвав кращим конкретним описом моральної поведінки: «Neminem laedo, imo omnes, quantum potes, juva! (Не роби шкоди нікому, але допомагай усім настільки, наскільки ти можеш)». Яр додає до цього: «Більш ніж за дві тисячі років до того як Артур Шопенгауер використав знання п'ятої заповіді, вона вже принесла такі знання з більшого аспекту ніж корись або шкода, а саме з точки зору святості життя та його проявів. Ми знаємо від Ісуса, що п'ята заповідь забороняє не тільки вбивство, але й неправомірні дії проти інших, злі слова, недобрі думки. Це означає: заповідь забороняє не тільки зловмисне або необережне знищення життя, а й усе, що таким чи іншим чином порушує або перешкоджає життю...».

Для протестантського пастора Фр. Яра віра у безсмертя є додатковою мотивацією для етичних дій не через страх бути покараним, а тому що Бог поважає життя і не дає йому минути просто так (2) (Jahr, 1934: 217218; 1938: 182-188).

(Б): Зобов'язання по відношенню до життя включають також в себе обов'язки щодо себе, підкреслює Яр у спогадах про роз'яснення М. Лютером п'ятої заповіді - «Не роби нікому шкоди в житті, але допомагай та заохочуй в усіх потребах тіла та життя, де б ти не був». Орієнтуючись на Послання до Коринфян $(3,16 f)$, Яр визначає: «Збереження життя, не виключаючи своє власне, є обов'язком. А знищення або пошкодження життя, знову ж таки і свого особистого, є етичним гріхом». Консервативний теолог описує цю диференційно-етичну конкретизацію обов'язку по самозбереженню та самозабезпеченню як критичну, з точки зору культури та часу, з чого виходять дефініції: «Як етичні обов'язки п'ятої заповіді практично впливають на особисте життя? Це виражається у неможливості позбавляти життя, вкорочувати його, послаблюючи своє здоров'я порочністю, нестриманістю у їжі та напоях, сильному гніві, легковажній нерозсудливості і таке інше. Особливо важливим є збереження статевої чистоти, а також запобігання зловживанням алко- 
гольними напоями». Стосовно першого твердження особливо чітким є міркування із Нового Заповіту: «Хто живе розпустою, той спричиняє злодіяння своєму власному життю» (Послання до Коринфян. 6, 18).

Але етичний обов'язок полягає не тільки в утриманні від розпусного життя, а, зокрема, й від усього, що спричиняє порочність: безсоромні погляди, нещира й двозначна мова, жарти й пісні, аморальні твори й картини, непорядні ігри, танці, відвертий одяг тощо. Порочне життя і зловживання алкогольними напоями може зашкодити не тільки власному життю, але й оточуючим, особливо власним нащадкам. «Невірно виконуючи свої духовні обов’язки, ми можемо нанести велику шкоду іншим людям. Наші нащадки будуть вразливими, тому що вони успадкували слабку й болящу природу, що як наслідок спричинить шкоду прийдешньому суспільству. Хто в цьому відношенні веде правильний спосіб життя, той тим самим виконує свій обов’язок перед суспільством. Також тому, хто є залежним від пияцтва, може загрожувати фізична й духовна небезпека. Також він ставить під загрозу не тільки самого себе, але й свою сім'ю, своїх нащадків, свій народ, свою расу» (Jahr, 1934: 184).

В іншій публікації, Яр наводив схожі соціально-етичні аргументи щодо того, що етика по відношенню до тварин не суперечить людській етиці, а доповнює та посилює іiі. Підхід Яра методологічно пов'язує етичний імператив до всього живого з новими вимірами індивідуальної та суспільної етики. Крайності людської поведінки, егоїзм й альтруїзм він вважає небажаними. Але баланс між «двома основними етичними проблемами, між їх протилежностями й союзі у соціальному житті» підкреслює роль здорової взаємодії обох принципів, як для розвитку індивідуума, так і для побудови і розвитку культури та суспільства. Зокрема, членство в організаціях, як і «колективний егоїзм» спільноти у цілому, здається Яру корисним і, тому є формою альтруїзму (Jahr, 1929: 341-346).

Яр також знався на вищезгаданих роботах Айслера та інших про взаємодію індивідуального життя з іншими біологічними системами, взаємозв'язки організмів у екосистемах.

(B): 3 третього й найдовшого розділу Яра під назвою «Біо-етичний імператив» основним положенням є «Не вбий!», так говорить нам п’ята заповідь. 3 поняттям «вбивство» співвідноситься термін «живе». Але живими організмами є не лише люди, але й тварини та рослини. Оскільки у формуванні п’ятої заповіді не ясно, чи заборонено вбивство тільки людини, чи не буде логічним поширити цю заборону на тварин та рослини?» (Jahr, 1934: 185). У відповідь на це питання Яр цитує вже згаданих авторів, підкреслюючи необхідність переходу від біопсихіки до біоетики. По суті, аргументи витікають з обох інших статей, а також з посилань на «параграфи охорони оточуючого середовища і тварин у різних 
високорозвинених країнах». Яр закінчує розділ наступними словами: «Універсальна сфера діяльності п’ятої заповіді виявляє себе у ставленні до всього живого. Інтерпретацією п'ятої заповіді виступає біо-етичний імператив: «Поважай кожне живе створіння перед усім як таке, чиє існування є самоціллю, і обходься з ним по можливості саме таким чином!».

\section{5. Етика в теорії та на практиці}

«Навчання образу мислення»: для Яра біоетичний імператив є не тільки об’єктом міжпредметного вивчення серед академічних дисциплін, а й практичним підходом щодо відповідальності та образу мислення. В одній із спеціальних статей 1930 року (як і у своєму есе 1927 року), Яр ще раз дискутує про взаємозв'язок етики та науки, але цього разу під питанням «диктатура образу мислення або ж свобода мислення?». Він розрізняє вирази з точки зору мислення та науки: «Образ мислення завжди так чи інакше підносить до морального судження. На противагу до будь-якого образу мислення наука не визнає такі оціночні судження основою своєї роботи». Звичайно, наука може обгрунтувати образ мислення, точніше кажучи, надати матеріал для цього (Jahr, 1930: 200-202). У переломні роки перед Третім Рейхом Фріц Яр виступає за ліберальне впровадження уроків етики та навчання критичному мисленню на уроках етики: «не дресирування, а лібералізація, точніше кажучи «демократизація» образу мислення».

Перші сім із його десяти тез говорять: «1. Не потрібно навчати якомусь фіксованому образу мислення. - 2. Суворо уникати того, що упереджена думка з ймовірною об'єктивністю та окрасою може бути фальшиво замаскована під так званий робочий образ мислення. - 3. Методично неприпустимо, розглядати тільки те, що відбувається та приховувати незручні факти, заперечувати або перекручувати по необхідності. - 4. Завжди брати до уваги різні точки зору. - 5. Навіть взаємо суперечливі переконання повинні розглядатися рівною мірою неупереджено у всіх своїх перевагах та помилках (Не так щоб одні розглядали щось через рожеві, а інші - через чорні окуляри). - 6. Якщо висловлюється особиста точка зору, то вона не повинна завжди обов'язково відбутись. Також не можна забувати проблематику своєї точки зору. - 7. Замість будь-якого тенденційного способу мислення учням повинна бути надана можливість сформувати свій особистий погляд або ж надати їм об'єктивний матеріал для подальшого формування свого образу мислення.

Дидактичні міркування Яра виходять за межі вузької методологічної суперечки між реформаторською педагогікою та традиційним патерналістичним вихованням, оскільки вони вказують на змістовну та ме- 
тодологічну ціль викладання етики та етичний дискурс. На думку Яра, етика не регулює філософські, теологічні чи політичні знання, не виступає як диктатура способу поведінки; етика - це ведення дискусій, культура обговорення, спілкування не стільки завдяки своїм теоретичним діям, скільки завдяки практиці. Отже, таким чином визначається методологічний канон для консультування по біоетичним питанням XXI століття, для сучасної медичної та клінічної етики, для спілкування між лікарем та пацієнтом, визначається форма вирішення конфліктів у світському та глобальному суспільстві, яка не втрачає актуальності по цей день. Стаття Яра з’явилась у журналі «Нове виховання. Альманах за вирішальну шкільну реформу та ліберальну шкільну політику» та була заборонена у 1933 році з початком загострення диктатури мислення націонал-соціалістами.

Із щоденної преси: Напередодні інформаційної епохи, епохи засобів масової інформації та швидкого розповсюдження радіо, Пастор Яр усвідомлює вплив сучасних 3МІ на поведінку та відношення між людьми. У статті «Соціальна та сексуальна етика у щоденних газетах» він віддає перевагу саме спеціалізованій пресі та публічним виступам на лекціях та курсах, але нарікає на погіршення відвідування таких заходів. Тому він як етик та педагог виявляє особливий інтерес і до щоденної преси (Jahr, 1928: 149-150). «Мільйони очей пробігають день у день мільйони стовпців у газетах. Навіть найважливіша спеціальна преса або найпопулярніша книга не завойовують такої популярності». Яр піднімає суперечливе питання: чи є щоденна газета виразом громадської думки або ж вона іiї формує? Так чи інакше, засоби масової інформації генерують громадську думку. Якщо ви шукаєте на шпальтах мотив, щоб сформувати громадську думку або намагаєтеся вплинути на неї, то, з точки зору етики, ви зобов'язані брати активну участь у формуванні ідей (у міру знань та совісті). До речі, практичні поради - справа професіоналів в етичній та газетній сферах. Використання цієї можливості рекомендується у сферах соціальної та сексуальної етики. Правила спілкування в спеціальній та щоденній пресі різні; фахівці з питань етики повинні це розуміти, i, наскільки це можливо, самим стати фахівцями з комунікації: «Якщо розглядати щоденну пресу як ту, яка зрідка подає невеликі етичні нариси і здатна завоювати інтерес та розуміння у непрофесіонала через фейлетонну форму, то, з цієї точки зору, значення преси для етики не можливо ігнорувати». 


\section{6. Сфери застосування поняття «біоетика»}

I хоч протягом 30 років розвитку біоетики твори Яра були невідомими, його погляди резонують із сучасними: Уорен Райх у 1995 році визначає біоетику як «the systematic study of human conduct in the area of the life sciences and health care, in as far as this conduct is examined in the light of moral values and principles» («систематичне вчення про поведінку людини в області природничих наук та здоров'язбереження, а також наскільки ця поведінка досліджена в контексті моральних цінностей та принципів»). Для термінологічного уточнення поняття біоетики автор пропонує вживати диференційовані прикметники відносно до сфер, які викликають заклопотаність в галузі біоетики: «to use the term bioethics in its original, global sense, as referring to the ethics of the life sciences and health care; and then use adjectives to specify particular areas of concern with bioethics. For example, one might speak of medical bioethics, environmental bioethics, clinical bioethics, or nursing bioethics without implying, with these terms, any particular approach» (Reich, 1995: 29). Як бачимо, така диференціація повністю співпадає із настановою Яра.

Саме чітка та зрозуміла термінологія в етиці є невід'ємною передумовою ясного та чіткого аналізу і оцінки, так само як у природничих науках (і в цьому біоетика схожа з природничими науками). Тому неможливо прийняти той факт, що сьогодні медико-етичні заклади, у тому числі Німеччини, називають себе «біоетичними», не припустимо використовуючи неясні судження. Це призводить до плутанини в осмисленні та оцінці.

Біоетику можна розуміти багатогранно: як науку, що оцінює вплив науково-технічного прогресу, як індивідуальну та професійну чесноту та характер, як соціальну ціль та обов'язок. І все для того, щоб чітко визначити взаємозв'язок індивідуальної, соціальної та економічної етики, що неодноразово підкреслював Яр, а також, шоб зробити зрозумілою нашу відповідальність за біологічний світ. В моделі Яра суспільні, економічні, соціальні та політичні відносини необхідно прирівнювати до відносин людини до тварин, рослин та космосу, як відносини між «живими істотами» як із нами, так і поміж собою. Давайте розуміти біоетику як загальне визначення відповідальності перед життям, а отже таку відповідальність можна сформулювати як категоричний імператив, який не залежить від реакції інших людей, а тільки від совісті, співчуття та відповідальності за своє життя та за життя інших. Під загальним терміном «біоетика» ми можемо об'єднати медичну етику, дослідницьку етику, клінічну етику, етику здоров’я, а також спеціальні ситуативні етичні проблеми, такі як аборти, евтаназія, генетичні маніпуляції з людьми, тваринами, рослина- 
ми та інше. Окремими напрямками були б міжгенераційна справедливість та етика форм спільного життя, спрямована не на окремих тварин чи рослин, а на природні або культурні середовища та біотопи.

Яр, виходячи з особливостей страждання окремої рослини або тварини, підкреслював, хоча й не так чітко як Айслер або як наші сучасні науковці, екологічний взаємозв'язок всього існуючого в умовах життя та під впливом фізичного та кліматичного навколишнього середовища як багатофункціональної живої істоти. Але він схематично зобразив процесуальний та інтерактивний характер життя як живого середовища на прикладах організації, установи, щоденної преси та освіти. Без сумніву, частиною цього є і гео-етика, яка тільки зараз фокусується у зв'язку з екологічними проблемами та природним глобальним потеплінням, щоб прояснити відповідальність перед нашою матінкою землею, і акцентувати на тому, що вона має своє власне життя, яке частково можна виміряти мільйонами років, частково відчути у порах року та їх відносній передбачуваності/непередбачуваності, більш довгими або короткими кліматичними змінами, які ми можемо визнати та культурно на них відреагувати: власне життя в своєму розвитку та змінах, котрі, в цілому, навряд чи можуть вплинути на нас людей, нагадує нам про свою гідність та вимагає від нас поваги; у зв'язку з чим ми не можемо і не повинні сприяти труднощам та звинуваченням. За думкою Яра, це одне із застосувань біоетичного імперативу.

Слідуючи філософії Канта і Яра, слід сформулювати наступний геоетичний імператив: «Поважай Матінку Землю $і$ все природнє життя як таке, за яке відповідальна людина, яке є самоціллю, і обходься з ним по можливості саме таким чином!». У повазі до живого виокремимо взаємовідносини між людиною і тваринами, рослинами, природою, включаючи систему охорони здоров'я, освітньо-, інформаційно-дослідні організації.

Яким би не був розвиток біоетики у майбутньому, її диференціації в глобальному діалозі між старою культурою і традиціями з новими техніками й знаннями, Пеллегріно в 1988 році зробив наступний прогноз: «Абсолютно точно можна передбачити, що зміни в біоетиці стануть ключовим здобутком в історії медицини та в історії людства» (3) (Sass, 1988: 17). Пастор із Галле на річці Залле Фріц Яр заклав для подальших «змін» вирішальну термінологічну й концептуальну базу.

\section{Примітки}

1. Фр. Яр. Три дослідження щодо 5-ї заповіді // Етика. Сексуальна та соціальна етика. - 1934. - № 11. - с. 183-187. - У дослідженні Вагнера «Парсифаль», пастор Фр. Яр порівнює страждання Ісуса та страждання короля Грааля із всеосяжною чеснотою - «співчуттям», яку він називає Любов’ю. Відповідно до сучасної 
релігійної думки світу з'являється «Парсифаль» як релігія буддистського співчуття, що опосередкована поглядами Шопенгауера. Шопенгауер бачить у цій релігійності контраст з християнством. Це не так. Хоча ми у фокусі мислення цього «всеосяжного» співчуття. Але є в християнстві любов (співчуття є лише ії формою), яка цінується вище, ніж будь-яке інше знання, знання, яке називають мудрістю (1 послання до Кор. 13). Те, що ми насправді маємо тут справу з християнськими цінностями, підтверджує Ніцше, який критикує твір «Парсифаль». Це справедливо для християнської релігії: Любов (яка проявляється як співчуття, як жалість) є основою і передумовою для будь-якого пізнання істини (Jahr, Fr. (1934). Zweifel an Jesus? Eine Betrachtung nach Richard Wagner's ,Parsifal'. Ethik. Sexual- und Gesellschaftsethik, 11, 363-364).

2. Для протестантського пастора Фріца Яра віра у безсмертя є додатковою мотивацією до етичних дій, але не через страх покарання, а тому, що Бог поважає життя (Jahr, Fr. (1934). Jenseitsglaube und Ethik im Christentum. Ethik. Sexual- und Gesellschaftsethik, 11, 217-218). В іншому місці твору він намагається пробудити можливість нового життя після земної смерті, порівнюючи ії з болем плода або досвідом плоду до і під час народження, який не може собі уявити, що після такого болю і уявленого кінця при народженні це і є справжнє життя, яке тільки починається, - схожий із порівнянним досвідом болю вмираючої та безнадійної людини (Jahr, Drei Abschnitte des Lebens nach 2. Korinther. Nach dem Gesetz und Zeugnis. Monatsschrift des Bibelbundes 38, 1938, S. 182-188).

3. У передмові до монографії Г.-М. Засса «Біоетика у США» відмічені слова Едмунда Пеллегріно, Голови Комісії з біоетики при Президенті Сполучених Штатів. Вони є й по цей день актуальним поглядом на майбутнє медицини та біоетики: «Малоймовірно, що можна дійти згоди щодо різнопланових питань, пов’язаних з нинішньої метаморфозою біомедичної етики, особливо з фундаментальними проблемами, що зачіпають життя людини. Тому, ми можемо тільки чекати на скорочення канонів загальнообов'язкових моральних концепцій, плюралізму правил або забороняючих заповідей. Речі, які, швидше за все, будуть загальновизнаними, виходять / виникають з самої природи медицини - iї «внутрішньої моралі». Але дещо й зміниться: принципи компетентності, співчуття, конфіденційних відносин, благополуччя пацієнта та процвітання медичних знань. А деякі нові принципи будуть активно включені, такі як повага автономії пацієнтів, прийняття рішення, згода на евтаназію / припинення безглуздих, неефективних методів лікування невиліковно хворих пацієнтів, повага заповідальних диспозицій, створення комітетів з етики, зростаюча участь в політиці та більш інтенсивний і більш відкритий моніторинг лікарів з точки зору їх компетенції. Питання у тому, яким чином ці зміни будуть проходити. Ми можемо очікувати широкий діапазон варіацій та зменшення знаходження консенсусу з таких питань як евтаназія «за власним бажанням», аборти, стерилізація, методи запліднення, генна інженерія тощо. Серед медичних професіоналів, як і в будь-яких інших професійних групах, з'явиться чітке визначення протилежних думок з таких питань, оскільки і серед них (як скрізь у суспільстві) існують такі ж глибокі і непереборні відмінності у релігійному чи філософському світоглядах. Можливо, найбільша турбулентність виходить через різновид інтерпретації того, що означає сама професія лікаря, особливо суперечки про те, скільки особистого зобов'язання вимагає медицина / мед. професія від виконуючих осіб (Sass, Н.-M. (1988). Bioethik in den USA, Heidelberg: Springer, S. 17). 


\section{Посилання / References}

Jahr, Fr. (1934). Drei Studien zum 5. Gebot. Ethik. Sexual- und Gesellschaftsethik, 11, 183187.

Jahr, Fr. (1934). Zweifel an Jesus? Eine Betrachtung nach Richard Wagner's, 'Parsifal'. Ethik. Sexual- und Gesellschaftsethik, 11, 363-364.

Jahr, Fr. (1934). Jenseitsglaube und Ethik im Christentum. Ethik. Sexual- und Gesellschaftsethik, 11, 217-218.

Jahr, Fr. (1938). Drei Abschnitte des Lebens nach 2. Korinther. Nach dem Gesetz und Zeugnis. Monatsschrift des Bibelbundes, 38, 182-188.

Jahr, Fr. (1929). Zwei ethische Grundprobleme in ihrem Gegensatz und in ihrer Vereinigung im sozialen Leben. Ethik. Sexual- und Gesellschaftsethik, 6, 341-346.

Jahr, Fr. (1930). Gesinnungsdiktatur oder Gedankenfreiheit? Gedanken über eine liberale Gestaltung des Gesinnungsunterrichts. Die neue Erziehung. Monatsschrift für entschiedene Schulreform und freiheitliche Schulpolitik, 12, 200-202.

Jahr, Fr. (1928). Soziale und sexuelle Ethik in der Tageszeitung Ethik. Sexual- und Gesellschaftsethik. Organ des ,Ethikbundes', 4(10/11), 149-150.

Reich, W.-T. (1995). The Word 'Bioethics'. The Struggle over its Meaning. Kennedy Institute of Ethics Journal, 5(1), 19-34.

Sass, H.-M. (1988). Bioethik in den USA, Heidelberg: Springer, 17.

\section{Ганс-Мартин Засс. Протестанские традиции основ биоэтики Перевод с немецкого и примечания Анны Губенко}

Термин и концепция биоэтики (Bio-Ethik) были разработаны Фрицем Яром (Fritz Jahr), протестантским пастором в городе Галле в 1927 году, то есть задолго до возникновения ее современного понимания в Америке в 1970-х и распространения по всему миру. Биоэтический императив Яра под влиянием христианских и гуманистических традиций (от Франциска Ассизского до Артура Шопенгауэра, а также буддийской философии) имеет свое собственное определение: «Уважай все живое как самого себя и, если это возможно, относись ко всему живому как к самому себе». Яр интерпретирует заповедь «Не убий» как принцип «общей морали», который включает в себя обязательства заботиться о своем здоровье, общественном здравоохранении и медико-санитарном просвещении в более широких рамках универсального биоэтического императива.

В статье акцентируются актуальные для настоящего времени мыслеполагания о термине «биоэтический императив», который выступает не только объектом междисциплинарного исследования, но и практическим подходом в приобретении чувства ответственности и экологического образа мышления. Дидактические рассуждения Яра выходят за пределы патерналистского воспитания, они указывают на содержательную и методологическую цель преподавания этики, на этический дискурс. По мнению Яра, этика не регулирует философские, теологические или политические знания, не выступает как диктатура способа поведения. Этика - это ведение дискуссий, культура обсуждения, общение. Следуя философии Яра, 
профессор Ганс-Мартин Засс сформулировал гео-этический императив: «Уважай Матушку Землю и жизнь как такую, за которую ответственен человек, которая является самоцелью, и поступай по возможности именно таким образом». Через уважение ко всему живому рассматриваются взаимоотношения между человеком и животными, растениями, природой в целом, включая систему здравоохранения, образовательные и исследовательские организации.

Пастор Фриц Яр, который во время своей жизни не имел непосредственного влияния на развитие концепции, тем не менее построил первую протестантскую основу для современных богословских и этических концепций в области медицинской этики, биоэтики и инвайронментальной этики.

Ключевые слова: Фрии, Яр, биоэтика, биоэтический императив, категорический императив, гео-этический императив.

\section{Hans-Martin Sass. Protestant traditions of the Backgrounds of Bioethics. Part 2.}

\section{Translation from German and Notes by Ganna Hubenko}

Term and concept of bioethics (Bio-Ethik) originally were developed by Fritz Jahr, a Protestant Pastor in Halle an der Saale in 1927, long before the period, when bioethics in the modern sense was recreated in the US in 1970s and since that time has spread globally. Jahr's bioethical imperative, influenced by Christian and humanist traditions from Assisi to Schopenhauer and by Buddhist philosophy holds its own position against Kant's anthropological imperative and against dogmatic Buddhist reasoning: 'Respect each living being as an end in itself and treat it, if possible, as such'. Jahr interprets the $5^{\text {th }}$ Commandment 'Thou shall not kill' offensively and liberally as 'common morality' which includes the obligation of caring for one's own health, public health and health education within the wider framework of a universal bioethical Sittengesetz.

In the article-translation the actual contemporary thoughts about the bioethical imperative, which serves not only the object of interdisciplinary study, but also the practical approach to acquiring responsibility and environmental image of thinking, are found. Didactic considerations of Yahr go beyond the paternalistic upbringing, they point to the content and methodological purpose of teaching ethics to ethical discourse. According to Yahr, ethics does not regulate philosophical, theological or political knowledge, does not act as a dictatorship of a way of behavior. Ethics is the conduct of discussions, the culture of discussion and communication. Following the philosophy of Yahr, Professor Hans-Martin Zass formulated the geo-ethical imperative: "Respect the Mother Earth and all natural life as it is, for which the responsible person is an end in itself, and get around as much as possible in this way!". In respect for all living things, there is a relationship between man and animals, plants, nature, including the health systems, educational-informational and research organizations. Pastor Fritz Jahr, who had no immediate influence during his times, built a strong first Protestant foundation for contemporary 
theological and ethical concepts in medical ethics, bioethics, and environmental ethics.

Keywords: Fritz Jar, bioethics, bioethical imperative, categorical imperative, geoethical imperative.

Ганс-Мартін Засс, Заслужений професор філософії Інституту філософії, Рурський університет, GA3, D44780 Бохум, Німеччина, e-mail:Hansmartin. Sass@rub.de

Засновник та член Правління Центру медичної етики NABF 04/297, D44780 Бохум, Німеччина, e-mail:Med.Ethics@ruhr-uni-bochum.de

Старший науковий співробітник Кеннеді Інституту Етики, Джорджтаунський університет, Вашингтон, округ Колумбія 20057, e-mail:SassHM@ aol.com

Почесний професор Наукового центру біоетики, Пекінський медичний коледж,

5 Донг Ден Сан Тяо, Пекін 100005, Китай, e-mail:SassHM@aol.com

Hans-Martin Sass, Emeritus Professor of Philosophy, Institut for Philosophie, Ruhr-Universitдt, GA3, D44780 Bochum, Germany, Hansmartin.Sass@rub.de

Founder and Member of the Board, Zentrum for Medizinische Ethik, NABF 04/297, D44780 Bochum, Germany, Med.Ethics@ruhr-uni-bochum.de

Emeritus Senior Research Scholar, Kennedy Inst. of Ethics, Georgetown Univ., Washington DC 20057, SassHM@aol.com

Honorary Professor, Research Center for Bioethics, Peking Union Medical College

5 Dong Dan San Tiao, Beijing 100005, PR China, SassHM@aol.com 